American Journal of Agricultural and Biological Science 2 (2): 75-80, 2007

ISSN 1557-4989

(C) 2007 Science Publications

\title{
Integrated Resource Recovery at East Calcutta Wetland: How Safe is These?
}

\author{
${ }^{1}$ Shaon Raychaudhuri, ${ }^{1}$ Sayali Salodkar, ${ }^{2}$ M. Sudarshan and ${ }^{1}$ Ashoke Ranjan Thakur \\ ${ }^{1}$ Department of Biotechnology, West Bengal University of Technology \\ BF-142, Sector 1, Salt Lake, Calcutta-700064 \\ ${ }^{2}$ UGC-DAE Consortium for Scientific Research, Calcutta Centre \\ III/LB-8, Bidhan Nagar, Calcutta-700064
}

\begin{abstract}
East Calcutta Wetland (ECW) is an example of wise use of cities solid and liquid waste through integrated resource recovery, mainly for pisciculture, vegetable as well as paddy cultivation and manure production. Amaranthus caudatus, Amaranthus blithum and Spinacia oleracea grown at ECW were analyzed for their accumulation of elements using Energy Dispersive X Ray Fluorescence (EDXRF) and compared to those grown in south eastern parts of West Bengal (Midnapur). The objective was to analyze the health hazard, if any, underlying the use of wastewater and solid waste for cultivation of green leafy vegetables at ECW. The following results were obtained upon comparing the data collected from the two different sites: (a) higher accumulation in ECW grown plants of elements like $\mathrm{Ca}, \mathrm{Cu}$ and $\mathrm{Pb}$ in Amaranthus caudatus; of $\mathrm{Ca}$ in Amaranthus blithum; of $\mathrm{Cl}$ and $\mathrm{Cu}$ in Spinacia oleracea, (b) for the same species grown in non-ECW site, higher concentration of elements like Mn and $\mathrm{Fe}$ in Amaranthus caudatus; of $\mathrm{Cl}, \mathrm{Mn}$ and $\mathrm{Br}$ in Amaranthus blithum; of $\mathrm{Ca}, \mathrm{Mn}, \mathrm{Fe}$ and $\mathrm{Br}$ in Spinacia oleracea. The net consumption of the aforementioned elements per person per day was calculated and found to be much below the Recommended Dietary Allowance (RDA) levels in all cases. Thus the vegetables grown out of integrated resource recovery mechanism at East Calcutta Wetland appear to be safe for human consumption. This further corroborated by the healthy appearance of these vegetables. This result has profound implications of far reaching significance for environmental management and health economics.
\end{abstract}

Key words: Integrated resource recovery, East Calcutta Wetland, EDXRF, recommended dietary allowance, bioaccumulation

\section{INTRODUCTION}

It has been reported that the continuous use of heavy metal contaminated sewage sludge as a fertilizer has resulted in transfer and accumulation of toxic metals from sludge to soil. The subsequent uptake and accumulation of metals in the edible parts of vegetative tissue results in a direct pathway into the human food chain ${ }^{[1]}$. Some phosphorus and trace element fertilizers may contain elevated amounts of toxic metals such as cadmium. Repeated uses of these fertilizers in large quantities over time increases cadmium uptake by plants like Lettuce (Lactuca sativa L. ${ }^{[2]}$. Metal concentrations in plant tissues grown in soil amended with mine wastes have shown variation in uptake and distribution of metals within different parts of the same plant as well as among different plants. Accumulation and translocation of lead, cadmium, arsenic and zinc were studied in tomato, bean, lettuce and radish. The lettuce leaves and the radish roots accumulated significantly more metals than bean and tomato fruits ${ }^{[3]}$. The uptake of cadmium, zinc and lead on the growth and metal content of celery grown in a ferric acrisol was not only affected by the individual elements, but also by combinations of the elements ${ }^{[4]}$. Studies showed that chromium content of vegetables of fruity and root types are higher as compared to the leafy type $\mathrm{e}^{[5]}$. On the other hand, higher level of accumulation of selenates $\left(\mathrm{Se}^{+6}\right)$ than selenites $\left(\mathrm{Se}^{+4}\right)$ was observed in the pulp as compared to the fruit skin in Tomato, Lycopersicum esculentum Mill plant ${ }^{[6]}$. Studies revealed that fly-ash application, particularly in higher amounts (4 and $8 \% \mathrm{w} / \mathrm{w}$ ) increased the $\mathrm{pH}$ and conductivity of soils to undesirable levels, although usage of relatively lower quantities favored plant growth and improved yields. Although the elements, viz. $\mathrm{Cd}, \mathrm{Cu}, \mathrm{Fe}, \mathrm{Mn}, \mathrm{Ni}$ and $\mathrm{Pb}$ accumulated in larger quantities in plants grown in fly-ash-amended soils than the control, their levels remained well below the threshold limit and, therefore the vegetables are suitable for human consumption at the lowest fly-ash application rate $(2 \% \mathrm{w} / \mathrm{w})$. The increase in the sugar content at the low fly-ash application rate in beet root, the second most important crop for sugar extraction, enhanced the possible application of fly-

Corresponding Author: Shaon Raychaudhuri, Department of Biotechnology, West Bengal University of Technology BF-142, Sector 1, Salt Lake, Calcutta-700064 
ash in tested amounts, in improving crop yields ${ }^{[7]}$. The composts produced solely from sludge or MSW (municipal solid waste) tended to be higher in metals such as $\mathrm{Cd}, \mathrm{Cu}, \mathrm{Hg}$ and $\mathrm{Zn}$ as compared to totally yard waste compost. Mo, $\mathrm{P}$ and Se were higher in composted sewage sludge and $\mathrm{Na}$ and $\mathrm{Pb}$ in composted MSW than in yard waste compost ${ }^{[8]}$. Previous research has demonstrated that many urban soils are enriched in $\mathrm{Pb}, \mathrm{Cd}$ and $\mathrm{Zn}$. Culture of vegetable crops in these soils could allow transfer of potentially toxic metals to foods. Lettuce yield on the urban garden soils was as great as or greater than that on the control soil. Lettuce $\mathrm{Cd}, \mathrm{Zn}$ and $\mathrm{Pb}$ concentrations increased from $0.65,23$ and $2.2 \mathrm{mg}$ $\mathrm{kg}^{-1}$ dry matter respectively in the control soil to as high as $3.53,422$ and $37.0 \mathrm{mg} \mathrm{kg}^{-1}$ respectively on the metal-rich urban garden soils. Urban garden soils caused a significant increase in lettuce leaf $\mathrm{Pb}$ concentration $^{[9]}$. Uptake of $U$ by vegetables and rice has shown lesser accumulation in former with increase in concentration of $U$ in irrigating water but with no effect of $U$ in soil. Again there was differential accumulation of $U$ in Rice plant with least accumulation in grain ${ }^{[10]}$. Metal levels in sugar cane (Saccharum spp.) samples from areas under the influence of municipal landfill and medical waste treatment system also showed indications of increased metal content in edible tissues of sugar cane $^{[11]}$.

Calcutta is foremost among South Asian Cities in the diversity of its informal waste-use traditions and their significance for the city's functioning. The city's swampy environs, a severe handicap for certain urban functions, provide a natural setting for waste treatment and reuse. For over a hundred years farmers, fishermen, scavengers and other groups have supported themselves in ecological niches in the extensive wetlands to the east of the city. Here ecological processes sustain socio-economic traditions that provide a living for perhaps a million people and are also responsible for significant production of vegetables and fish for the metropolitan area. The entire solid waste of the metropolis is dumped at East Calcutta Wetland (ECW) while the liquid sewage passes through ECW before reaching its final destination. Here waste mediated environmental pollution is prevented using natural microbial resource operating at ECW. The liquid sewage is treated in the sewage-fed fisheries, a costeffective and lasting process. A number of fisheries purify this water through a series of sedimentation processes and use the water for fish cultivation and agriculture. The tropical region is naturally suitable for using solar radiation to improve wastewater quality. ECW was designated as a Ramsar Site (Wetland of International Importance as per the
Ramsar Convension) in November $2002^{[12,13,14]}$.

The resource recovery system at ECW consists of three areas. Firstly, the Sewage-fed fisheries called Bheris that produce about $8,000 \mathrm{t}$ fish annually. Secondly, the garbage farms yield 150 tonnes of fresh vegetables daily and finally the paddy fields produce 16,000 tonnes of winter paddy varieties cultivated during post monsoon period annually. The old solid waste dumping grounds have been converted into cultivable lands. Effluents from the waste water fed fisheries are spread over the land as manure and water from these are used for irrigation of crops grown in these fields. The wetland ecosystem is one of the rare examples of combination of environmental protection and development management. Thus, ECW is a perfect example of wise use of wetland ecosystem where usage of city sewage for traditional practices of fisheries and agriculture is practiced ${ }^{[12,13 \text {, }}$

14]. The key question that needs to be answered at this stage concerns the safety, quality and reliability of the products obtained from the East Calcutta Wetland. This is the precise question that we set out to answer in this paper. Our study concentrates on the vegetables produced from this region. We feel that our own contribution to the problem outlined above lies in carrying out the relevant analysis, arriving at the conclusions and finally indicating their significance.

The X Ray Fluorescence method is widely used to measure the elemental composition of materials. Since this method is fast and non-destructive to the sample, it is the method of choice for field applications and industrial production for control of materials. Depending on the application, XRF can be produced by using not only X-rays but also other primary excitation sources like alpha particles, protons or high energy electron beams. In this study, the concentration of different elements was measured using Energy Dispersive $X$ ray Fluorescence technique. Different elements in green leafy vegetables like Amaranthus caudatus, Amaranthus blithum and Spinacia oleracea from ECW sites and also distant places (non-ECW sites) were studied. These vegetables were chosen because these are the most commonly consumed vegetables of this region.

\section{MATERIALS AND METHODS}

Sample collection and study area: The green leafy vegetables namely Amaranthus caudatus, Amaranthus blithum and Spinacia oleracea were collected from various sites of ECW and non ECW. The ECW lie sapproximately between $22^{\circ} 25^{\prime}$ to $22^{\circ} 40^{\prime}$ latitude North and $88^{\circ} 20^{\prime}$ to $88^{\circ} 35^{\prime}$ longitude East. Midnapur (non ECW site) is located in the 
south western part of West Bengal, at the border of the neighbouring state of Orissa.

Sample preparation: The green leafy vegetables were washed with tap water and rinsed with distilled water. The edible parts of these green leafy vegetables were then air dried over a period of two days. Each of the samples was then dried separately in micro oven. The duration of microwave drying varied for each sample. The dried vegetable was grinded in blender. The powdered form from the blender was sieved using $100 \mathrm{~m}$ sieve. $400 \mathrm{mg}$ of the sieved powder was measured and pellets were made using Pelletizer $(110 \mathrm{Kg} / \mathrm{sq}$. cm). Five pellets of each sample of vegetable were prepared.

Sample analysis: The elemental compositions of the pellets prepared for vegetables were determined using EDXRF (Energy Dispersive X Ray Fluorescence) technique. This is a fast, nondestructive, multi-elemental technique and involves bombarding the samples by X-rays from an $\mathrm{X}$-ray tube, resulting in emission of characteristic Xrays. The energy of these X-rays is signatures of the presence of the elements whereas their intensities are a measure of their concentrations. A Jordan Valley EX-3600 EDXRF system was used in the present study. This consists of a X-ray generator (X-ray tube ( $\mathrm{Rh}$ anode) and its power unit), a $\mathrm{Si}(\mathrm{Li})$ detector (with resolution of $143 \mathrm{eV}$ at $5.9 \mathrm{keV}$ ) for the detection of the emitted characteristic X-rays. Elements from $\mathrm{Na}-\mathrm{U}$ can be detected using this system. The X-rays from the sample reach the detector through a thin $(0.00125 \mathrm{~mm})$ Be window. The concentrations were measured in $\mu \mathrm{g} / \mathrm{g}$. This system consists of an automated sample chamber where 10 samples can be mounted at a time. The quantitative analysis is carried out online, by the inbuilt ExWin software.

Statistical analysis and data evaluation: The Standard Deviation of the data collected was computed using the following equation:

S.D. $=\sqrt{ }\left[\Sigma\left(\mathrm{Xi}-\mathrm{X}_{\mathrm{m}}\right)^{2} /(\mathrm{n}-1)\right]$, where $\mathrm{Xi}$ denotes the ith observation, $X_{m}$ is mean of the observations and $n$ stands for the number of observations.

The mean of the observations was calculated and the difference of each observation from the mean was obtained. Each such difference was squared and the squared values were added to get the sum of squares. This sum was divided by the number of observations minus one to get mean-squared deviation, called variance. The square root of the variance gives us root-mean squared deviation, called standard deviation.
For each set of data, standard deviation (S.D.) was calculated and graphs of elements vs its concentration were plotted using Origin 6.1 software. To determine the relative intake per person per day of each vegetable, the net consumption after cooking was determined. From there the corresponding wet and dry weights and also the actual elemental concentration in the given amount were calculated. This value was used to determine the daily consumption of a person of the different elements.

\section{RESULTS AND DISCUSSION}

The concentrations for the elements: $\mathrm{P}, \mathrm{S}, \mathrm{Cl}, \mathrm{K}$, $\mathrm{Ca}, \mathrm{V}, \mathrm{Cr}, \mathrm{Mn}, \mathrm{Fe}, \mathrm{Co}, \mathrm{Ni}, \mathrm{Cu}, \mathrm{Zn}, \mathrm{As}, \mathrm{Se}, \mathrm{Br}, \mathrm{Rb}, \mathrm{Sr}$ and $\mathrm{Pb}$ were determined by EDXRF for both the $\mathrm{ECW}$ and the non-ECW vegetables. Elements showing appreciable variations between ECW and Non-ECW samples are mentioned in the Table 1 and Graph 1 for Amaranthus caudatus, Table 2 and Graph 2 for Amaranthus blithum and Table 3 and Graph 3 for Spinacia oleracea.

Table 1: Represents the metal concentration in $\mu \mathrm{g} / \mathrm{g}$ of dry weight in Amaranthus caudatus as evident from EDXRF analysis

\begin{tabular}{lll}
\hline Element & $\begin{array}{l}\text { ECW } \\
\text { Mean } \pm \text { S.D. } \\
(\mu \mathrm{g} / \mathrm{g})\end{array}$ & $\begin{array}{l}\text { Non ECW } \\
\text { Mean } \pm \text { S.D. } \\
(\mu \mathrm{g} / \mathrm{g})\end{array}$ \\
\hline $\mathrm{Ca}$ & $21898 \pm 2962.4$ & $18296 \pm 1323.94$ \\
$\mathrm{Mn}$ & $37.2 \pm 2$ & $121.52 \pm 6.86$ \\
$\mathrm{Fe}$ & $767.98 \pm 67.48$ & $3867 \pm 172.69$ \\
$\mathrm{Cu}$ & $15.34 \pm 0.914$ & $6.79 \pm 0.27$ \\
$\mathrm{~Pb}$ & $5 \pm 0.57$ & $0.072 \pm 0.16$ \\
\hline
\end{tabular}

Table 2: Indicates the metal concentration in $\mu \mathrm{g} / \mathrm{g}$ of dry weight in Amaranthus blithum as evident from EDXRF studies

\begin{tabular}{lll}
\hline Element & $\begin{array}{l}\text { ECW } \\
\text { Mean } \pm \text { S.D. } \\
(\mu \mathrm{g} / \mathrm{g})\end{array}$ & $\begin{array}{l}\text { Non ECW } \\
\text { Mean } \pm \text { S.D } \\
(\mu \mathrm{g} / \mathrm{g})\end{array}$ \\
\hline $\mathrm{Cl}$ & $5372 \pm 170.12$ & $17668 \pm 1153.33$ \\
$\mathrm{Ca}$ & $17954 \pm 1190.68$ & $5262 \pm 280.96$ \\
$\mathrm{Mn}$ & $33.92 \pm 1.89$ & $242.32 \pm 6.207$ \\
$\mathrm{Br}$ & $8.684 \pm 0.642$ & $38.99 \pm 1.82$ \\
\hline
\end{tabular}

Table 3: Shows the metal concentration in $\mu \mathrm{g} / \mathrm{g}$ of dry weight in Spinacia oleracea as evident from EDXRF data

\begin{tabular}{lll}
\hline Element & $\begin{array}{l}\text { ECW } \\
\text { Mean } \pm \text { S.D. } \\
(\mu \mathrm{g} / \mathrm{g})\end{array}$ & $\begin{array}{l}\text { Non ECW } \\
\text { Mean } \pm \text { S.D. } \\
(\mu \mathrm{g} / \mathrm{g})\end{array}$ \\
\hline $\mathrm{Cl}$ & $12424 \pm 1306$ & $6305.8 \pm 453.11$ \\
$\mathrm{Ca}$ & $9107.8 \pm 755.24$ & $16034 \pm 652.44$ \\
$\mathrm{Mn}$ & $36.4 \pm 1.22$ & $79.06 \pm 4.56$ \\
$\mathrm{Fe}$ & $203.92 \pm 11.08$ & $2073.8 \pm 40.43$ \\
$\mathrm{Cu}$ & $36.56 \pm 1.13$ & $9.66 \pm 1.43$ \\
$\mathrm{Br}$ & $8.095 \pm 0.462$ & $36.66 \pm 2.02$ \\
\hline
\end{tabular}




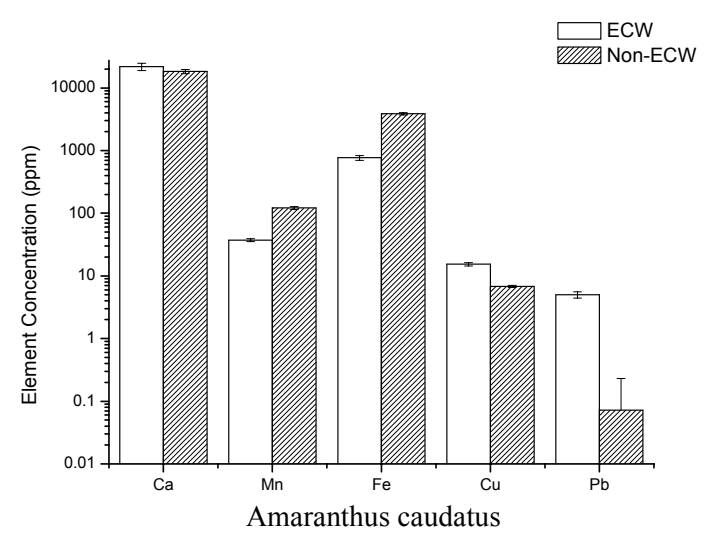

Fig. 1: Graphical representation of the elemental composition in Amaranthus caudatus from ECW and Non CW sites. The $\mathrm{X}$-axis represents the elements while the $\mathrm{Y}$-axis represents their concentration in ppm

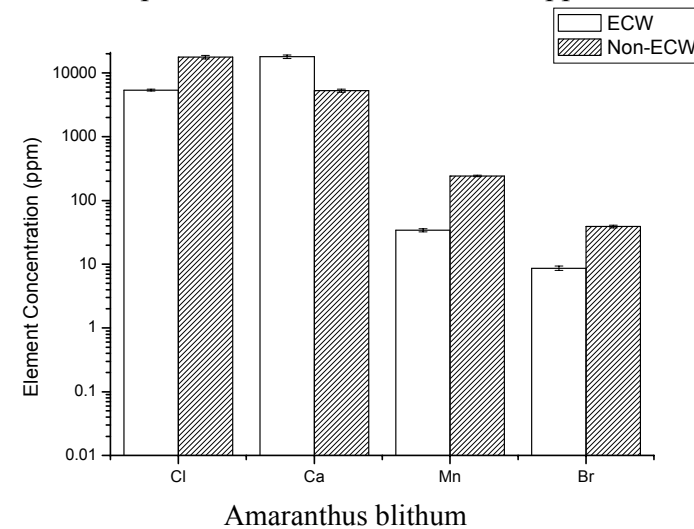

Fig. 2: Graphical representation of the elemental composition in Amaranthus blithum from ECW and Non ECW region. The $\mathrm{X}$-axis represents the elements while the $\mathrm{Y}$-axis represents their concentration in ppm

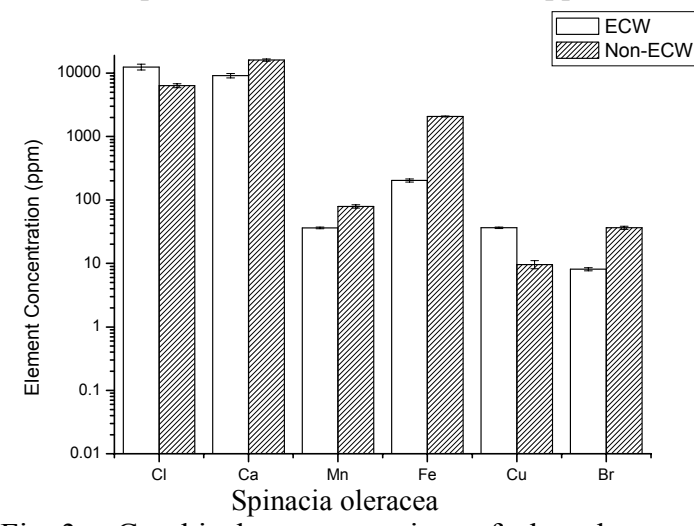

Fig. 3: Graphical representation of the elemental composition in Spinacia oleracea from ECW and Non ECW location. The X-axis represents the elements while the $\mathrm{Y}$-axis represents their concentration in ppm
$\mathrm{Ca}$ and Mn showed marked differences in ECW and Non ECW values for all the three vegetables. The concentration of $\mathrm{Mn}$ and Fe is lower in ECW as compared to the non-ECW vegetables. There was significant accumulation of $\mathrm{Pb}$ in Amaranthus caudatus $(5 \pm 0.57) \mu \mathrm{g} / \mathrm{g}$ from ECW. For Amaranthus blithum and Spinacia oleracea it can be seen that $\mathrm{Br}$ concentration is almost four times less in ECW as compared to Non ECW. Other elements which showed variation were $\mathrm{Cl}$ and $\mathrm{Cu}$. For the remaining metals the elemental concentrations were moderately same for both ECW and Non ECW vegetables. This is the net result of element accumulation in vegetables from the two sites.

Our next objective was to determine the amount of element (in $\mathrm{mg} / \mathrm{g}$ ) in vegetables consumed by one person. For this it was initially found that $30 \mathrm{~g}$ wet weight (for Amaranthus caudatus and Spinacia oleracea) and $37.5 \mathrm{~g}$ wet weight (for Amaranthus blithum) gives $3 \mathrm{~g}$ dry weight (for Amaranthus caudatus and Spinacia oleracea) and $5 \mathrm{~g}$ dry weight (for Amaranthus blithum) respectively. For this study $0.4 \mathrm{~g}$ dry weight of the vegetables were taken to prepare each pellet. That in turn corresponds to $4 \mathrm{~g}$ wet weight (for Amaranthus caudatus and Spinacia oleracea) and $3 \mathrm{~g}$ wet weight (for Amaranthus blithum) respectively. This amount is equivalent to the consumption of 4 people. Thus the mean value mentioned in the above Tables (1, 2 and 3 ) corresponded to these respective wet weights. From this the amount of element (in $\mathrm{mg}$ ) in vegetable consumed by one person was calculated. Tables 4,5 and 6 compare the daily consumption of element concentration in vegetable with the recommended dietary value.

Let us now briefly outline the importance of the elements that are under consideration in the human physiological system. For example, calcium is critical for strengthening bones and teeth and is necessary for proper nervous system and immune function. It assists in muscle contraction, blood clotting and blood pressure. Inadequate calcium intakes have been associated with increased risk of preeclampsia, hypertension and colon cancer.

Copper helps make red blood cells, is part of several body enzymes and is important for absorption of iron. Skeletal abnormalities, reproductive difficulties, impaired nervous tissue function and changes in hair and skin pigmentation have been observed in severe copper deficiency.

Iron is involved in energy metabolism as an oxygen carrier in hemoglobin and as a structural component of cytochromes in electron transport. Iron is a structural component at the catalytic site of a large number of enzymes covering a wide array of diverse metabolic functions. These include neurotransmitter synthesis and function, phagocyte antimicrobial activity, hepatic detoxification systems 
Am. J. Agri. \& Biol. Sci., 2 (2): 75-80, 2007

Table 4: Represents comparison of the concentration of different elements in Amaranthus caudatus with the recommended dietary value

\begin{tabular}{llll}
\hline Element & $\begin{array}{l}\text { Recommendation } \\
(\mathrm{mg} / \text { day) }\end{array}$ & $\begin{array}{l}\text { Element in Amaranthus caudatus from } \\
\text { ECW consumed by 1 person (mg/day) }\end{array}$ & $\begin{array}{l}\text { Element in Amaranthus caudatus from } \\
\text { Non-ECW consumed by 1 person (mg/day) }\end{array}$ \\
\hline $\mathrm{Ca}$ & $1000-1200$ & $164.23 \pm 22.22$ & $137.22 \pm 9.93$ \\
$\mathrm{Mn}$ & $2-5$ & $0.28 \pm 0.015$ & $0.91 \pm 0.05$ \\
$\mathrm{Fe}$ & $10-15$ & $5.76 \pm 0.506$ & $29 \pm 1.295$ \\
$\mathrm{Cu}$ & $1.5-3$ & $0.12 \pm 6.9 \times 10^{-3}$ & $0.051 \pm 0.002$ \\
$\mathrm{~Pb}$ & - & $0.04 \pm 4.3 \times 10^{-3}$ & $0.0005 \pm 0.0012$ \\
\hline
\end{tabular}

\begin{tabular}{llll} 
Table 5: & \multicolumn{4}{l}{ Shows comparison of the concentration of different elements in Amaranthus blithum with the recommended dietary value. } \\
\hline Element & $\begin{array}{l}\text { Recommendation } \\
(\mathrm{mg} / \text { day) }\end{array}$ & $\begin{array}{l}\text { Element in Amaranthus blithum from } \\
\text { ECW consumed by 1 person (mg/day) }\end{array}$ & $\begin{array}{l}\text { Element in Amaranthus blithum from } \\
\text { Non-ECW consumed by 1 person (mg/day) }\end{array}$ \\
\hline $\mathrm{Cl}$ & 750 & $67.15 \pm 2.13$ & $220.85 \pm 14.42$ \\
$\mathrm{Ca}$ & $1000-1200$ & $224.42 \pm 14.88$ & $65.775 \pm 3.512$ \\
$\mathrm{Mn}$ & $2-5$ & $0.425 \pm 0.023$ & $3.03 \pm 0.077$ \\
$\mathrm{Br}$ & - & $0.108 \pm 8 \times 10^{-3}$ & $0.487 \pm 0.023$ \\
\hline
\end{tabular}

Table 6: Indicates the comparison of the different element's concentration in Spinacia oleracea with the recommended dietary value

\begin{tabular}{llll}
\hline $\begin{array}{c}\text { Element } \\
\text { (mg/day) }\end{array}$ & Recommendation & Element in Spinacia oleracea from & Element in Spinacia oleracea from Non- \\
$\mathrm{Cl}$ & 750 & ECW consumed by 1 person (mg/day) & ECW consumed by 1 person (mg/day) \\
$\mathrm{Ca}$ & $1000-1200$ & $93.18 \pm 9.79$ & $47.29 \pm 3.4$ \\
$\mathrm{Mn}$ & $2-5$ & $68.31 \pm 5.66$ & $120.25 \pm 4.89$ \\
$\mathrm{Fe}$ & $10-15$ & $0.27 \pm 9.2 \times 10^{-3}$ & $0.59 \pm 0.034$ \\
$\mathrm{Cu}$ & $1.5-3$ & $1.52 \pm 0.08$ & $15.55 \pm 0.3$ \\
$\mathrm{Br}$ & - & $0.27 \pm 8.5 \times 10^{-3}$ & $0.07 \pm 0.01$ \\
\hline
\end{tabular}

and synthesis of DNA, collagen and bile acids. Iron deficiency anemia is the most common nutritional deficiency disease. Other symptoms of iron deficiency with or without clinically detectable anemia include short attention span, apathy, irritability, hypoactivity and impaired cognitive development in children. In the adult population, iron deficiency contributes to poor immunocompetence, irregular heartbeat and fatigue. Paleness of oral mucosal tissue, concave pale nail beds and behavioral changes can also signify the presence of iron deficiency. Lead has certain toxic effects which include liver and kidney damage, gastro-intestinal damage, mental retardation and abnormalities in fertility and pregnancy.

Manganese is a cofactor for enzymes involved in hydrolysis, phosphorylation, decarboxylation and transamination. It also promotes activities of transferases such as glycosyltransferase and of glutamine synthetase and superoxide dismutase. Manganese deficiency in humans has not been documented. Bromine has unknown physiological function and $\mathrm{Rb}$ is not an essential element.

\section{CONCLUSION}

All the elements mentioned in the foregoing discussion have distinctive roles for the normal physiology of the body. Variations do exist in the levels of elements in the vegetables grown at ECW. Yet all of them are much below the RDA. The preceding study conclusively establishes, for the first time, that the vegetables grown at ECW are absolutely safe for human consumption. Since the meal does not consist of only vegetables, but has other constituents as well, the elements which are deficient in these vegetables get compensated from other food sources. By straightforward generalization, one can say that the resource recovery process practised at ECW is safe, reliable and of standard quality. It may be mentioned in this connection that chemical processes involved in waste treatment are prohibitively expensive and therefore bioremediation is the alternative method of choice wherever applicable. However, at ECW, the entire detoxification process is free from any type of chemical treatment and is purely driven by natural mechanisms. The products generated by the Integrated Resource Recovery mechanism at ECW have been found to be of acceptable quality. At the same time, it is true that the resource recovery system in place at ECW leads to significant cost savings and nurtures the ecosystem of the entire region. Hence it is very proper to assert that this mechanism is not only safe from the physiological viewpoint, but also productive from the economic and environmental perspectives.

\section{ACKNOWLEDGEMENTS}

The authors would like to acknowledge the financial support of Department of Science and Technology, India as well as Department of 
Biotechnology, India. They would also like to acknowledge the technical assistance of Mr. Bidhan Mohanty and Mr. Ajay Rathor of UGC-DAE Consortium for Scientific Research, Calcutta Centre and Mr. Animesh Pahari for carrying out and initiating this work. They would like to thank Dr. Indranil Mukherjee of Army Institute of Management for his help during preparation of the manuscript.

\section{REFERENCES}

1. Chandra Sekhar, K., R. Supriya, C.T. Kamala, N.S. Chary, T.N. Rao and Y. Anjaneyulu, 2002. Speciation, Accumulation of Heavy Metals in Vegetation Grown on Sludge Amended Soils and their Transfer to Human Food Chain - A Case Study. Toxicolo. and Environ. Chem., 82: 33-43.

2. Huang, B.A., S.A. Kuo and R.A. Bembenek, 2003. Cadmium uptake by Lettuce from soil amended with phosphorus and Trace element fertilizers. Water, Air and Soil Pollution., 14: 109-127.

3. Cobb, G.P., K. Sands, M. Waters, B.G. Wixson and E. Dorward-King, 2000. Accumulation of heavy metals by vegetables grown in mine wastes. Environmental Toxicolo. and Chem., 19: 600-607.

4. Haiyan, W., 2003. Effect of $\mathrm{Cd}, \mathrm{Zn}$ and $\mathrm{Pb}$ compound pollution on celery in a Ferric Acrisol. Soil and Sediment Contamination., 12: 357-370.

5. Khairiah, J., Y.H. Yin, K.N. Ibrahim, A.W. Wee, A. Aminah, A. Maimon, M.K. Zalifah and G.A.K. Giber, 2002. Bioavailability of Chromium in vegetables of selected agricultural areas of Malaysia. Pak. J. Bio. Sci., 5: 471- 473.

6. Golubkina, N.A., A.A. Zhumaev and G.B. Dem'yanova-Roi, 2003. Pattern of Selenium Distribution in Tomato Lycopersicum esculentum Mill. Biology Bulletin., 30: 468 471.
7. Singh, N., S.N. Singh, M. Yunus and K.J. Ahmad, 1994. Growth response and element accumulation in Beta vulgaris L. raised in flyash-amended soils. Ecotoxicology (Historical Archive)., 3: 287 - 298.

8. Lisk, D.J., W.H. Gutenmann, M. Rutzke, H.T. Kuntz and G. Chu, 1992. Survey of toxicants and nutrients in composted waste materials. Archives of Environmental Contamination and Toxicology., 22: 190-194.

9. Sterrett, S.B., R.L. Chaney, C.H. Gifford and H.W. Mielke, 1996. Influence of fertilizer and sewage sludge compost on yield and heavy metal accumulation by lettuce grown in urban soils. Environ. Geochem. and Health., 18: 135-142.

10. Lakshmanan, A.R. and K.S. Venkateswarlu, 1988. Uptake of Uranium by vegetables and rice. Water, Air and Soil Pollution (Historical Archive)., 38: 151-155.

11. Segura-Munoz, S.I., A. da Silva Oliveira, M. Nikaido, T.M.B. Trevilato, A. Bocio, A.M.M. Takayanagui and J.L. Domingo, 2006. Metal levels in sugar cane (Saccharum spp.) samples from an area under the influence of a municipal landfill and a medical waste treatment system in Brazil. Environ. Inter., 32: 52-57.

12. Chakraborti, D., D. Ghosh and S. Niyogi, 1987 Calcutta Pollutants: Part 1: Appraisal of some heavy metals in Calcutta City Sewage and sludge in use for fisheries and agriculture. Intern J. Environ. Anal. Chem., 30: 243-253.

13. Ghosh, D., 1993. Towards sustainable development of the Calcutta Wetlands; towards the wise use of wetlands. In Ramsar Convention (ed Davis, T.S.), pp: 107-112.

14. Furedy, C. and D. Ghosh, 1984. Resourceconserving traditions and waste disposal: the garbage farms and sewage-fed fisheries of Calcutta. Conservation and Recycling., 7: 159165. 